\title{
Factors Influencing Income of Shallot Farming in Java Indonesia Using UOP Profit Function Model
}

\author{
Susanawati \\ Department of Agribusiness \\ Universitas Muhammadiyah Yogyakarta \\ Yogyakarta, Indonesia \\ susanawati@umy.ac.id \\ Jamhari \\ Department of Social Economic \\ Universitas Gadjah Mada \\ Yogyakarta, Indonesia \\ jamhari@ugm.ac.id
}

\author{
Masyhuri \\ Department of Social Economic \\ Universitas Gadjah Mada \\ Yogyakarta, Indonesia \\ dr_masyhuri@yahoo.com \\ Dwidjono Hadi Darwanto \\ Department of Social Economic \\ Universitas Gadjah Mada \\ Yogyakarta, Indonesia \\ dwidjonohd.sosek@ugm.ac.id
}

\begin{abstract}
The purpose of this study was to calculate farming income of shallot and analyze the factors that influenced it. This study was conducted in Java precisely in Brebes, Nganjuk, and Cirebon Regency because these regions are the centre of shallot production in Indonesia. The respondents were 90 shallot farmers in three locations selected by simple random sampling. The data were one of the planting seasons of shallot in every location in 2014. Income from shallot farming can be calculated by income approach. UOP profit function was used to analyze the factors influencing the income from shallot farming. The result of this study showed that the highest income from shallot farming was in Nganjuk, followed by Cirebon and Brebes. The price of seed influenced the income from shallot farming in Brebes and Cirebon. Labor cost and the price of insecticide influenced the income from shallot farming in Brebes and Nganjuk. The income from shallot farming in Cirebon was affected by the price of KCL fertilizer, NPK-Phonska fertilizer, and herbicide. The price of ZA fertilizer influenced the income from shallot farming in Brebes. The price of SP 36 fertilizer had an effect on the income from shallot farming in Nganjuk.
\end{abstract}

Keywords—farming income, shallot, UOP profit function

\section{I.INTRODUCTION}

Shallot (Allium ascalonicum) is one of the most economically important vegetable for nationwide consumption in Southeast Asia [1]. Shallots contain a lot of useful ingredients for human life, especially as flavor to Indonesian dishes [2]. The production of bulb shallot is restricted to highland areas under rain-fed conditions [3]. Vegetable plants are commodities that have high economic value and play an important role in the fulfillment of various needs of farmer groups [4]. Shallot plants are one of horticultural commodities which have sufficient potential because many people have widely developed some types of shallot commodities and these commodities have quite good market opportunities. These commodities are also a source of income and provide employment opportunities and have a high contribution to regional economic development. Shallots are a major source of flavoring in fresh and cooked food, and are the second most important horticultural crop after tomatoes. They are used, produced and traded worldwide. Bulb onions vary in flavor, from very mild to extremely pungent when tasted uncooked [5]
Shallot plant is one of the horticultural commodities which has potential to be developed [6]. The benefit of shallot is as a source of carbohydrate, vitamin A, B, and C [7]. According to [8], in shallot contains a component called allin, which is a compound containing amino acid that is odorless, colorless and soluble in water. Shallots are used in soups, salads, and sauces, as well as as food seasoning [9]. Shallot production takes less than three months (60-80 days) from planting to harvest. Indonesian farmers produce shallots during three production periods i.e. planting in February/March, May/June, and August/September [10]. According to [11], the regions in Java that produce shallot are West Java, Central Java, Yogyakarta, East Java and Banten. Brebes is the largest shallot-producing region in the province of Central Java, for being able to contribute to $67.83 \%$ out of the total shallot production in this province and the remaining $(32.17 \%)$ comes from non-shallot producing cities. The shallot production in East Java Province in 2012 reached 222.862 thousand tones or about 24.47 thousand tones $(12.3 \%)$ in comparison to the previous year 2011 that only reached 198.388 thousand tons. In these cases, 168,220 tons of shallot were from Nganjuk Regency, the rest was from Probolinggo Regency (42.07 tons and Pamekasan Regency of 12.57 tons. This shows that Nganjuk Regency is the center of shallot production in East Java.

Shallot-producing areas in West Java Province are Cirebon, Majalengka, Bandung, and Garut [12]. Over a span of 2005 to 2009, the average shallot productions of the four regencies were 36,228 tons, 32,949 tons, 10,634 tons, and 3,418 tons, respectively. Based on these data, it can be concluded that Cirebon Regency is the main shallot producer in West Java Province although there are some regencies that produce small quantity of shallot.

The shallot production pattern in Java generally uses monocultures and relay cropping. The growing season of shallot in Cirebon is three times a year in April - December for farmers who are close to water sources and in April August for farmers who are far from water sources. In addition, the widely used cropping pattern by farmers is sugar cane-shallot-shallot-shallot-sweet corn. The growing season of shallot in Brebes Regency is also three times a year, i.e. in April - May, July - August, and October - November, and the cropping pattern is paddy-shallot-shallot-shallot. On the other 
hand, Nganjuk cultivates shallots only twice a year, i.e. in June-July and in September-October with a cropping pattern of paddy-soybean-shallot-shallot [12].

Shallot farming needs high production costs and has high production risks. One of the impacts is that farmers receive less income. Hence, it is necessary to conduct research aimed at knowing the income from shallot farming in Java and the factors affecting the revenue. The result of this research can be used as information for farmers to improve farming.

\section{METHODS}

The research locations were selected deliberately, i.e. Cirebon, Brebes, and Nganjuk Regency because all those three regencies were the centers of shallot production in Java, even in Indonesia. Based on the data of shallot production in 2010 there were 14 subdistricts in Cirebon that produced shallots. Gebang Subdistrict was an area with the highest shallot production, so this subdistrict was selected as a location of this research. From these selected subdistricts, one which had the highest shallot production was selected, i..e Gebang Village. From a population of approximately 150 shallot farmers who were the members of Sari Tani farmer group, 30 farmers were randomly selected as the respondents.

Wanasari Subdistrict of Brebes Regency had the highest volume of shallot production, so this subdistrict was selected as a location of this research. There were four villages in Wanasari Subdistrict as producers of shallot in large quantities, namely Jagalempeni, Tegalgandu, Sidamulya, and Klampok. Among these four villages, Sidamulya was deliberately selected because the village had a farmers group namely Mulya Tani farmers group which had 125 members divided in three groups: Sido Makmur (75 people), Sido Panen (25 people), and Sido Dadi (25 people). This research selected Sido Makmur because this group had the most members, and among the members, 30 people were selected randomly as the sample.

In Nganjuk Regency, there were 17 shallot-producing subdistricts and Rejoso was one of the subdistricts with the largest production, so this subdistrict was selected as a location of this research. Sukorejo was the village that produced shallots in the largest quantities in Rejoso Subdistrict, Nganjuk Regency. There were three farmers groups in the village, namely Sido Makmur Jaya, Makmur, and Margo Makmur. Among these three farmers group, Sido Makmur Jaya had the most members, i.e. 170 members, and from this group, 30 members were selected randomly as the sample of this research.

The data in this research were primary data, covering various components of farming costs and the farmgate price of shallot. Gross income is all values from the production of goods received, self-consumed, given to others as wages and used in the next production process [13]. [14] defined revenue as the value of the overall production of agricultural commodities before reduced by production costs. Revenue according to Soekartawi [14] is calculated from the volume multiplied by the price per unit of production:

$\mathrm{TR}=\mathrm{Y} . \mathrm{P}_{\mathrm{y}}$

where :

$\mathrm{TR}=$ Total Revenue (IDR)
$\mathrm{Y}=$ Output (unit)

$\mathrm{P}_{\mathrm{y}}=$ Price of Output (IDR)

According to Wattimena [13], the calculation of farming income can be done by two approaches: income approach and profit approach. In this research, the farming income was calculated using income approach by using the following formula:

$$
\begin{aligned}
& \mathrm{NR}=\mathrm{TR}-\mathrm{TC} \\
& \mathrm{NR}=\mathrm{TR}-(\mathrm{TVC}+\mathrm{TFC}) \\
& \mathrm{NR}=\mathrm{Py} . \mathrm{Y}-(\mathrm{Px} \cdot \mathrm{X}+\mathrm{TFC})
\end{aligned}
$$

$$
\begin{aligned}
& \text { where }: \\
& \text { NR = Net Revenue } \\
& \text { TR = Total Revenue } \\
& \text { TC = Total Cost } \\
& \text { TFC = Total Fixed Cost } \\
& \text { TVC = Total Variable Cost } \\
& \text { Py = Unit Price of Output } \\
& \text { Y = Quantity of Output } \\
& \text { Px = Unit Price of Input } \\
& \text { X = Quantity of Input }
\end{aligned}
$$

In a production process, the relationship between the factors of production (input) with output in physical form is shown by the production function. The production function is an equation that includes factors of production in such a way that for every combination of certain factors of production there are only a certain number of results. Factors of production that can be controlled largely determine the success of farmers [16]. Profit Function Analysis: The theory of profit function, which was developed to help overcome the problem of simultaneous equation bias, if present. Another distinct advantage of this approach over production function is that with the help of duality theorem (Shephard, 1953) on [17], the variable factor demand function and supply function of products can be derived directly from the estimated profit function. The factors that affected the income from shallot farming were analyzed using Unit Output Price Profit Function Model (UOP Profit Function Model). According to [18], the use of UOP profit function model is believed to have several advantages compared with a production function and linear programs, such as (1) output supply function and input demand function can be predicted simultaneously without having to make a an explicit production function; (2) profit function can be used to review technical, price, and economic efficiency; and (3) in profit function, the variables observed are the variables of unit prices of output and input.

The Cobb-Douglas Profit Function is used to determine the relationship between input and output, and to measure the impact of various changes on the input prices on the production [19]. According to [20], the assumptions used in the UOP Profit Function Model are (a) farmers as units of economic analysis seek to maximize profits; (b) farmers buy inputs and sell outputs in perfect competition markets or farmers serve as price takers; and (c) the production function is a concave form in non-fixed inputs.

UOP profit function model used in this research is: 


$$
\begin{aligned}
& \operatorname{Ln} \pi^{*}=\operatorname{Ln} A^{*}+\alpha_{1}{ }^{*} \operatorname{Ln}_{-} \mathrm{W}_{1}+\alpha_{2}{ }^{*} \mathrm{Ln}_{-} \mathrm{W}_{2}+\alpha_{3}{ }^{*} \mathrm{Ln}_{-} \mathrm{W}_{3}+\alpha_{4}{ }^{*} \mathrm{~L}_{-} \mathrm{W}_{4}+\alpha_{5}{ }^{*} \mathrm{Ln}_{-} \mathrm{W}_{5}+\alpha_{6}{ }^{*} \mathrm{Ln}_{-} \mathrm{W}_{6} \\
& +\alpha_{7}{ }^{*} \mathrm{~L}_{-} \mathrm{W}_{7}+\alpha_{8}{ }^{*} \mathrm{Ln}_{-} \mathrm{W}_{8}+\alpha_{9}{ }^{*} \mathrm{Ln}_{-} \mathrm{W}_{9}+\beta_{1}{ }^{*} \mathrm{Ln}_{-} \mathrm{Z}_{1}+\mathrm{e}_{0}
\end{aligned}
$$

where:

$$
\begin{aligned}
& \pi^{*}=\text { normalized farmer income } \\
& \mathrm{A}^{*}=\text { intercept } \\
& -\mathrm{W}_{1}=\text { normalized seed price } \\
& -\mathrm{W}_{2}=\text { normalized price of urea fertilizer } \\
& -\mathrm{W}_{3}=\text { normalized price of } \mathrm{KCl} \text { fertilizer } \\
& -\mathrm{W}_{4}=\text { normalized price of TSP fertilizer } \\
& -\mathrm{W}_{5}=\text { normalized price of NPK-Phonska fertilizer } \\
& -\mathrm{W}_{6}=\text { normalized price of herbicide } \\
& -\mathrm{W}_{7}=\text { normalized price of insecticide } \\
& -\mathrm{W}_{8}=\text { normalized price of fungicide } \\
& -\mathrm{W}_{9}=\text { normalized wage rate } \\
& \mathrm{Z}_{1}=\text { land area } \\
& \alpha_{1-9} *=\text { estimated variable input parameter } \\
& \beta_{1} *=\text { estimated fixed input parameter } \\
& \mathrm{e}_{0}=\text { error factor }
\end{aligned}
$$$$
\text { The hypotheses are: }
$$

Ho : $\alpha_{\mathrm{i}}{ }^{*}=\beta_{\mathrm{i}}{ }^{*}=0$, there is no significant influence of the independent variable on the dependent variable

Ha : $\alpha_{i}^{*} \neq \beta i^{*} \neq 0$, there is significant influence of the independent variable on the dependent variable

The hypothesis testing was done with coefficient of determination, $\mathrm{F}$ test, and $\mathrm{t}$ test, as follows:

Coefficient of determination is a testing whether the use of regression equation of coefficient of determination is accurate, where the value indicates the proportion of the total dependent variable $\mathrm{Y}$ that is described by regression lines (independent variable $\mathrm{X}$ ). When the regression line is right in the average value of $Y$, then $E S S=0$, so that $R^{2}=0$. So, the coefficient of determination is between 0 and 1 . The higher the value of $\left(\mathrm{R}^{2}\right)$ or nearing 1 , the better the regression model, which means that the independent variable can explain the dependent variable from the regression model (Widarjono) [20]. Mathematically formula $\mathrm{R}^{2}$ can be written down as follows:

$$
\mathrm{R}^{2}=\frac{\mathrm{ESS}}{\mathrm{TSS}}=\frac{\sum\left(\hat{\mathrm{Y}}_{\mathrm{j}}-\overline{\mathrm{Y}}\right)^{2}}{\sum\left(\mathrm{Y}_{\mathrm{i}}-\overline{\mathrm{Y}}\right)^{2}}
$$

where:

$\mathrm{R}^{2}=$ coefficient of determination

$\hat{\mathrm{Y}}=$ estimated dependent variable

$\bar{Y}=$ mean value of independent variable

$\mathrm{Yi}=\mathrm{i}$-th observation value of dependent variable

ESS $=$ explained sum of squares

TSS $=$ total sum of square

$\mathrm{F}$ test is basically used to know the influence of independent variable simultaneously on dependent variables (Widarjono) [20]. The hypotheses used are as follows:

$\mathrm{H}_{0}: \mathrm{b} 1=\mathrm{b} 2=\mathrm{b} 3=\ldots . .=\mathrm{bn}=0$,
This means that all independent variables simultaneously do not have influence on dependent variable.

Ha $: \mathrm{b} 1 \neq \mathrm{b} 2 \neq \mathrm{b} 3 \neq \ldots \ldots \ldots \neq \mathrm{bn} \neq 0$,

This means that all independent variables simultaneously have significant influence on dependent variable.

$\mathrm{F}$ statistic $\mathrm{F}$ was calculated using this equation:

$$
\mathrm{F}=\frac{\mathrm{R}^{2} /(\mathrm{k}-1)}{\left(1-\mathrm{R}^{2}\right) /(\mathrm{n}-\mathrm{k})}=\frac{\mathrm{ESS} /(\mathrm{k}-1)}{\mathrm{TSS} /(\mathrm{n}-\mathrm{k})}
$$

$\mathrm{F}$ critical value is based on the value of $\alpha$ and $\mathrm{df}$ determined by numerator (k-1) and df for denominator (n-k). The decision to reject or accept Ho is as follows:

When F count $>\mathrm{F}$ table, then Ha is accepted and Ho is rejected. This means that independent variables simultaneously have significant effect on dependent variables or there is dependence of dependent variable on independent variables in regression.

When $\mathrm{F}$ count $<\mathrm{F}$ table, then Ho is accepted and $\mathrm{Ha}$ is rejected. This means that independent variables simultaneously do not have significant effect on dependent variables.

T test is used to know the partial influence of independent variables with the following hypotheses:

Ho : bi $=0$, meaning that independent variables have no influence on dependent variable.

Ha : bi $\neq 0$, meaning that independent variables have significant influence on dependent variable.

The testing rules are: if $t$-count $>t$-table , Ho is rejected and $\mathrm{Ha}$ is accepted, meaning that the $\mathrm{i}$-th independent variable has significant impact on dependent variable. Both t count and $t$ table can be expressed as follows:

$$
\begin{aligned}
& \mathrm{t}-\text { count }=\frac{\mathrm{bi}}{\mathrm{Sbi}} \\
& \mathrm{t} \text { table }=(\mathrm{n}-\mathrm{k} ; \alpha / 2)
\end{aligned}
$$

where:

bi $=$ estimated parameter

Sbi $=$ standard error of estimated parameter

$\mathrm{n}=$ number of samples

$\mathrm{k}=$ number of independent variables

\section{III.RESULT AND DISCUSSION}

\section{A. Shallot Farming Income}

The average land areas for the shallot farming in Cirebon, Brebes, and Nganjuk were 0.666 hectares, 0.496 hectares, and 0.254 hectares, respectively. The average production of shallot in these three regencies can be seen in Table 1.

Table 1. Average of farming production of shallot per hectare 


\begin{tabular}{lrr}
\hline \multirow{2}{*}{ Location } & \multicolumn{2}{c}{ Average production } \\
\cline { 2 - 3 } & Kilogram & \multicolumn{1}{c}{ Ton } \\
\hline Cirebon Regency & $16,260.48$ & 16.26 \\
Brebes Regency & $9,663.43$ & 9.66 \\
Nganjuk Regency & $20,570.58$ & 20.57 \\
\hline
\end{tabular}

Based on Table 1, the average shallot production in Nganjuk was the highest, followed by Cirebon and Brebes. The high productivity achieved by shallot farmers in Nganjuk was due to several factors, among others (1 ) the shallot variety cultivated in Nganjuk was Thai shallot variety that has

Table 2. Revenue, cost, and income from shallot farming per hectare

\begin{tabular}{|c|c|c|c|c|}
\hline \multirow{2}{*}{\multicolumn{2}{|c|}{ Explanation }} & \multicolumn{3}{|c|}{ Research Location } \\
\hline & & Cirebon & Brebes & Nganjuk \\
\hline \multicolumn{2}{|c|}{ Production $(\mathrm{kg})$} & $16,260.48$ & $9,663.43$ & $20,570.58$ \\
\hline \multicolumn{2}{|c|}{ Price (IDR $/ \mathrm{kg}$ ) } & $5,463.30$ & $5,403.70$ & $4,308.33$ \\
\hline \multicolumn{2}{|c|}{ Revenue (IDR) } & $88,835,880.38$ & $52,788,539.78$ & $88,744,586.17$ \\
\hline \multicolumn{2}{|c|}{$\begin{array}{l}\text { Variable Cost } \\
\text { (IDR) }\end{array}$} & $\begin{array}{r}61,195,325.29 \\
(92.78)\end{array}$ & $\begin{array}{r}34,645,157.85 \\
(82.92)\end{array}$ & $\begin{array}{r}32,151,027.65 \\
(71.94)\end{array}$ \\
\hline 1. & Seeds & $\begin{array}{r}27,754,941.00 \\
(42.08)\end{array}$ & $\begin{array}{r}15,713,138.83 \\
(39.88)\end{array}$ & $\begin{array}{r}15,387,413.00 \\
(34.43)\end{array}$ \\
\hline 2. & $\begin{array}{l}\text { Fertili } \\
\text { zer }\end{array}$ & $\begin{array}{r}6,268,929.00 \\
(9.51)\end{array}$ & $\begin{array}{r}4,103,745.08 \\
(10.41)\end{array}$ & $\begin{array}{r}2,954,130.00 \\
(6.61)\end{array}$ \\
\hline 3. & $\begin{array}{l}\text { Pestic } \\
\text { ide }\end{array}$ & $\begin{array}{r}5,954,491.00 \\
(9.02)\end{array}$ & $\begin{array}{r}2,082,819.88 \\
(5.29)\end{array}$ & $\begin{array}{r}2,854,877.57 \\
(6.39)\end{array}$ \\
\hline 4. & $\begin{array}{l}\text { Non } \\
\text { Famil } \\
\text { y } \\
\text { Labor }\end{array}$ & $\begin{array}{r}21,216,964.29 \\
(32.17)\end{array}$ & $\begin{array}{r}12,745,454.06( \\
32.35)\end{array}$ & $\begin{array}{r}11,954,606.18 \\
(26.75)\end{array}$ \\
\hline Fixed $\mathrm{Co}$ & (IDR) & $\begin{array}{r}4,761,462.00 \\
(7.22)\end{array}$ & $\begin{array}{r}4,758,094.75 \\
(12.06)\end{array}$ & $\begin{array}{r}12,539,506.00 \\
(28.06)\end{array}$ \\
\hline & $\begin{array}{l}\text { Land } \\
\text { Rent }\end{array}$ & $\begin{array}{r}4,517,984.00 \\
(6.85)\end{array}$ & $\begin{array}{r}4,373,821.04 \\
(11.10)\end{array}$ & $\begin{array}{r}12,315,608.00( \\
27.56)\end{array}$ \\
\hline 2. & $\begin{array}{l}\text { Depre } \\
\text { ciatio } \\
\mathrm{n}\end{array}$ & $\begin{array}{r}243,478.00 \\
(0.37)\end{array}$ & $\begin{array}{r}384,273.71 \\
(0.98)\end{array}$ & $\begin{array}{r}223,898.00 \\
(0.50)\end{array}$ \\
\hline Total Co & (IDR) & $\begin{array}{r}65,956,787.29(1 \\
00.00)\end{array}$ & $\begin{array}{r}39,403,252.61 \\
(100.00)\end{array}$ & $\begin{array}{r}44,690,533.65 \\
(100.00)\end{array}$ \\
\hline Income & & $22,879,093.09$ & $13,385,287.17$ & $44,054,052.52$ \\
\hline
\end{tabular}

Based on Table 2, shallot farmers in Cirebon had the highest production costs although the highest price of shallots at the farmer level was also found in Cirebon. On the other hand, the lowest price of shallots at the farmer level was found in Nganjuk Regency, but this regency had the highest productivity, leading to the highest income among the three study locations, followed by Cirebon and Brebes. In terms of the cost structure, seed cost had the highest contribution to the total costs of shallot farming in all the research locations. This result is in accordance with a research by [23] i.e. An Analysis of Farming and Marketing Margins of Shallot in Brebes Regency which showed that seed cost has the highest contribution to the total costs of farming. In addition, a research by [24] i.e. Efficiency of Shallot Market Management showed that the largest cost of shallot farming is seed cost, followed by labor cost. The Indonesian government has been promoting the use of true seed shallot (TSS) for shallot production because this has a higher productivity and could greatly reduce the risk of disease transfer [25]. the potential of high production; (2) cropping patterns that is beneficial for the soil by cultivating leguminous plants (soybean) before shallot, that can naturally improve the nitrogen content in the soil, allowing shallots to grow optimally. The productivity of shallot farmers in Cirebon was also higher than that in Brebes because these farmers cultivated sugar cane before shallot; the plants have long roots so they can absorb more nutrients. [22] noted that the process of curing of onion bulbs is most effective if the harvested bulbs are removed from the field for drying within 48 hours of topping.

\section{B. Factors Influencing Shallot Farming Income with UOP Profit Function Model}

Table 3. Results of analysis of factors influencing shallot farming income

\begin{tabular}{|c|c|c|c|c|c|c|}
\hline \multirow[b]{2}{*}{ Variable } & \multicolumn{2}{|l|}{ Cirebon } & \multicolumn{2}{|l|}{ Brebes } & \multicolumn{2}{|l|}{ Nganjuk } \\
\hline & $\begin{array}{l}\text { Coefficie } \\
n t\end{array}$ & $\begin{array}{l}\text { Pro } \\
\text { b. }\end{array}$ & $\begin{array}{l}\text { Coefficie } \\
\text { nt }\end{array}$ & $\begin{array}{l}\text { Pro } \\
\text { b. }\end{array}$ & $\begin{array}{l}\text { Coefficie } \\
\text { nt }\end{array}$ & $\begin{array}{l}\text { Pro } \\
b .\end{array}$ \\
\hline Constant & 7.276 & $\begin{array}{l}0.07 \\
5\end{array}$ & -12.402 & $\begin{array}{l}0.09 \\
6\end{array}$ & -0.964 & $\begin{array}{l}0.59 \\
7\end{array}$ \\
\hline Seed price & $-0.703^{*}$ & $\begin{array}{l}0.06 \\
6\end{array}$ & $-1.031^{*}$ & $\begin{array}{l}0.07 \\
1\end{array}$ & -0.431 & $\begin{array}{l}0.15 \\
2\end{array}$ \\
\hline $\begin{array}{l}\text { Price of } \\
\text { urea } \\
\text { fertilizer }\end{array}$ & 0.742 & $\begin{array}{l}0.46 \\
3\end{array}$ & 1.573 & $\begin{array}{l}0.44 \\
7\end{array}$ & 0.001 & $\begin{array}{l}0.98 \\
3\end{array}$ \\
\hline $\begin{array}{l}\text { Price of ZA } \\
\text { fertilizer }\end{array}$ & -0.217 & $\begin{array}{l}0.77 \\
2\end{array}$ & $-6.520^{* *}$ & $\begin{array}{l}0.01 \\
7\end{array}$ & -0.034 & $\begin{array}{l}0.27 \\
1\end{array}$ \\
\hline $\begin{array}{l}\text { Price of SP } \\
36 \\
\text { fertilizer }\end{array}$ & 0.895 & $\begin{array}{l}0.23 \\
1\end{array}$ & -0.364 & $\begin{array}{l}0.83 \\
9\end{array}$ & $-0.034^{* *}$ & $\begin{array}{l}0.05 \\
6\end{array}$ \\
\hline $\begin{array}{l}\text { Price of } \\
\mathrm{KCl} \\
\text { fertilizer }\end{array}$ & $-0.741^{* * *}$ & $\begin{array}{l}0.02 \\
4\end{array}$ & 2.819 & $\begin{array}{l}0.14 \\
7\end{array}$ & 0.019 & $\begin{array}{l}0.24 \\
0\end{array}$ \\
\hline $\begin{array}{l}\text { Price of } \\
\text { urea NPK- } \\
\text { Phonska } \\
\text { fertilizer }\end{array}$ & $-2.555^{* * *}$ & $\begin{array}{l}0.01 \\
6\end{array}$ & 1.530 & $\begin{array}{l}0.52 \\
2\end{array}$ & 0.016 & $\begin{array}{l}0.45 \\
7\end{array}$ \\
\hline $\begin{array}{l}\text { Herbicide } \\
\text { price }\end{array}$ & $-0.313^{*}$ & $\begin{array}{l}0.07 \\
1\end{array}$ & -0.269 & $\begin{array}{l}0.34 \\
6\end{array}$ & 0.025 & $\begin{array}{l}0.19 \\
9\end{array}$ \\
\hline $\begin{array}{l}\text { Fungicide } \\
\text { price }\end{array}$ & 0.172 & $\begin{array}{l}0.45 \\
0\end{array}$ & -0.228 & $\begin{array}{l}0.51 \\
1\end{array}$ & -0.016 & $\begin{array}{l}0.46 \\
1\end{array}$ \\
\hline $\begin{array}{l}\text { Insecticide } \\
\text { price }\end{array}$ & 0.105 & $\begin{array}{l}0.16 \\
0\end{array}$ & $-0.512^{* * *}$ & $\begin{array}{l}0.00 \\
0\end{array}$ & $-0.046^{*}$ & $\begin{array}{l}0.06 \\
6\end{array}$ \\
\hline Labor cost & -0.051 & $\begin{array}{l}0.90 \\
2\end{array}$ & $-1.806^{* *}$ & $\begin{array}{l}0.01 \\
0\end{array}$ & $-1.531^{* * *}$ & $\begin{array}{l}0.00 \\
1\end{array}$ \\
\hline Land area & 0.167 & $\begin{array}{l}0.38 \\
7\end{array}$ & 0.013 & $\begin{array}{l}0.96 \\
0\end{array}$ & $2.531^{* * *}$ & $\begin{array}{l}0.00 \\
0\end{array}$ \\
\hline $\begin{array}{l}\text { Coefficient } \\
\text { Value } \\
\text { determinati } \\
\text { on }\left(\mathrm{R}^{2}\right)\end{array}$ & 0.521 & & 0.670 & & 0.755 & \\
\hline $\begin{array}{l}\text { F count } \\
\text { value }\end{array}$ & $3.872^{* * *}$ & & $6.344^{* * * *}$ & & $9.138^{* * *}$ & \\
\hline
\end{tabular}

Based on Table 3, the coefficients of determination or $\mathrm{R}^{2}$ for the analysis in the three research locations were 0.521 , 0.670 , and 0.755 , respectively. These values show that the variations of dependent variable can be explained by the variations of independent variables i.e. $52.1 \%, 67 \%$, and $75.5 \%$, respectively, while the remaining i.e. $47.9 \%, 33 \%$, and $24.5 \%$ were explained by the variations of other independent variables not included in the model. The f count for the three research locations indicated a high significance level of $99 \%$, meaning that the independent variables used in the analysis simultaneously had effect on the dependent variables with a confidence level of $99 \%$.

The $\mathrm{t}$ test showed that the price of seeds, price of $\mathrm{KCl}$ fertilizer, the price of NPK-Phoska fertilizer, and price of herbicides had significant influence on farmer income in Brebes. The income from shallot farming in Brebes was significantly influenced by the price of seed, the price of ZA fertilizer, price of insecticide, and labor costs. The price of SP 36 fertilizer, price of insecticide, labor cost, and land area 
affected the income from shallot farming in Nganjuk Regency. This result is in line with a statement from [26] that shallots need the availability of some nutrients i.e. nitrogen $(\mathrm{N})$, phosphorus $(\mathrm{P})$ and potassium $(\mathrm{K})$ in sufficient and balanced quantities in the soil to be able to grow and produce optimally. NPK Phonska and $\mathrm{KCl}$ fertilizers can increase the growth and yield of shallots.

The regression coefficient for the variable of seed prices in the three locations was as expected, i.e. having negative sign and being significant at a confidence level of $90 \%$ in Cirebon and Nganjuk, whereas that in Nganjuk Regency was not significant. This means that when there is an increase in the price of seeds relative to the prices of shallot while other variables remain the same, then the incomes from shallot farming in the three locations will decrease at a confidence level of $90 \%$. When there is an increase in the price of seeds relative to the price of shallots in Nganjuk Regency while other variables remain the same, then there is a tendency of decreasing the income from shallot farming in this region.

The regression coefficient for the variable of urea fertilizer price in the three research locations had positive sign, and was insignificant. This means that, if there is an increase in the price of urea fertilizer relative to the price of shallots in each location while other variables remain the same, then there is a tendency of increasing the farming income in Cirebon, Brebes, and Nganjuk. The regression coefficient for the variable of ZA fertilizer price in all the research locations had negative sign. This value was significant at a confidence level of $95 \%$ for the analysis results in Brebes, but insignificant in Cirebon and Nganjuk. This means that, if there is an increase in the price of ZA fertilizer relative to the price of shallot in Brebes while other variables remain the same, then there is a tendency of decreasing the income from shallot farming with a confidence level of $90 \%$. When there is an increase in the price of ZA fertilizer relative to the price of shallot in Cirebon and Nganjuk while other variables remain the same, then there is a tendency to decrease the income from shallot farming in the two locations. 
The regression coefficient for the variable of SP 36 fertilizer price for the analysis in Cirebon Regency had positive sign and was insignificant. The regression coefficients in Brebes and Nganjuk were both negative; this was insignificant in Brebes but significant at a confidence level of $95 \%$ in Nganjuk. This shows that the regression coefficient for Cirebon was not as expected, while those in Brebes and Nganjuk were as expected. If there is an increase in the price of SP 36 fertilizer relative to the price of shallots in Cirebon and Brebes while other variables remain the same, then there is a tendency that shallot farmers income in Cirebon will increase, while the income from shallot farming in Brebes tends to decrease. When there is an increase in the price of SP 36 fertilizer relative to the price of shallot in Nganjuk while other variables remain the same, then there is a tendency that the income from shallot farming in this regency will decrease at a confidence level of $95 \%$.

In Table 3, it can be seen that the regression coefficient for the variable of $\mathrm{KCl}$ fertilizer price in Cirebon had negative sign and was significant at a confidence level of $95 \%$, while those in Brebes and Nganjuk were positive and insignificant. This shows that the variable of $\mathrm{KCl}$ fertilizer price for the analysis in Brebes and Nganjuk was not as expected, while that in Cirebon was as expected. This means that if there is an increase in the price of $\mathrm{KCl}$ fertilizer relative to the price of shallots in Cirebon while other variables remain the same, then the income from shallot farming would decrease at a confidence level of $95 \%$. When there is an increase in the price of $\mathrm{KCl}$ fertilizer relative to the price of shallot in Brebes and Nganjuk while other variables remain the same, there is a tendency that the income from shallot farming in both locations will increase.

The regression coefficient for the variable of NPKPhonska fertilizer price in Cirebon was negative and significant at a confidence level of $99 \%$, while those in Brebes and Nganjuk were positive and insignificant. This shows that the regression coefficient for the analysis in Cirebon was as expected while those in Brebes and Nganjuk were not. This means that, if there is an increase in the price of NPk-Phonska fertilizer relative to the price of shallot in Cirebon while other variables remain the same, then the income from shallot farming will decrease at a confidence level of $99 \%$. If there is an increase in the price of NPK-Phonska fertilizer relative to the price of shallot in Brebes and Nganjuk while other variables remain the same, then there is a tendency that the income from shallot farming in the two research locations will increase.

The regression coefficients for the variable of herbicide price in Cirebon and Brebes were negative; this was significant at a confidence level of $90 \%$ in Cirebon, but insignificant in Brebes. The regression coefficient for the analysis in Nganjuk was positive and insignificant. This shows that the regression coefficients for the price of herbicides in Cirebon and Brebes were as expected, while that in Nganjuk was not. This means that, if there is an increase in the price of herbicides relative to the price of shallot in Cirebon while other variables remain the same, it will reduce the income of shallot farming at a confidence level of $90 \%$. Similarly, when there is an increase in the price of herbicides relative to the price of shallot in Brebes while other variables remain the same, there is a tendency to lower the income from shallot farming in Brebes. On the other hand, when there is an increase in the price of herbicides relative to the price of shallot in Nganjuk while other variables remain the same, there is a tendency to raise the income from shallot farming in Nganjuk.

The regression coefficient of the fungicide price in Cirebon was positive and insignificant, while those in Brebes and Nganjuk were negative and insignificant. This shows that the regression coefficients in Brebes and Nganjuk were as expected, while that in Cirebon was not. This means that, if there is an increase in the price of fungicide relative to the price of shallot in Cirebon while other variables remain the same, then there is a tendency to raise the income of shallot farming. When there is an increase in the price of fungicide relative to the price of shallot in Brebes and Nganjuk while other variables remain the same, then there is a tendency to reduce the income from shallot farming in the two research locations.

The the regression coefficient of the price of insecticide in Cirebon was positive and insignificant. The regression coefficients in Brebes and Nganjuk were negative and significant at different confidence levels, i.e. $99 \%$ for the analysis in Brebes and $90 \%$ for that in Nganjuk. This shows that the regression coefficients of the price of insecticide in Brebes and Nganjuk were as expected, while that in Cirebon was not. This means that, if there is an increase in the price of insecticide relative to the price of shallot in Cirebon while other variables remain the same, and then there is a tendency to raise the income from shallot farming in Cirebon. If there is an increase in the price of insecticide relative to the price of shallot in Brebes and Nganjuk while other variables remain the same, then the income from shallot farming in both of these regencies tend to decrease at confidence levels of $95 \%$ and $90 \%$.

The regression coefficients of the variable of labor cost for the analysis in Cirebon, Brebes, and Nganjuk were negative. The value for the analysis in Cirebon was not significant, while those for Brebes and Nganjuk were significant at different confidence levels, i.e. $95 \%$ and $99 \%$. This shows that the regression coefficients of the labor costs in Cirebon, Brebes, and Nganjuk were as expected. When there is an increase in labor cost relative to the price of shallot in Cirebon, Brebes, and Nganjuk while other variables remain the same, then there is a tendency to lower the income from shallot farming in Cirebon and there is a certainty to lower the income from shallot farming in Brebes and Nganjuk at confidence levels of $95 \%$ and $99 \%$., respectively

The regression coefficients of the variable of land area in Cirebon, Brebes, and Nganjuk were all positive. The values were insignificant for the analysis in Cirebon and Brebes, but significant in Nganjuk at a confidence level of $99 \%$. This indicates that the regression coefficients of land area for the analysis in all the three regencies were as expected. This means that, if there is an increase in the land area in Cirebon and Brebes while other variables remain the same, then there is a tendency to raise the income from shallot farming in Cirebon and Brebes. If there is an increase in the land area in Nganjuk while other variables remain the same, then this will definitely raise the income from shallot farming in the region. 


\section{IV.CONCLUSION}

Nganjuk has the highest productivity and farming income, followed by Cirebon and Brebes Regency. In all the research locations, Seed costs have the highest contribution to the total costs of shallot farming, followed by labor costs in Cirebon and Brebes, and land rental costs in Nganjuk. The price affects the income of shallot farming in Cirebon and Brebes. The price of insecticides and labor costs affect the income of shallot farming in Brebes and Nganjuk. The prices of $\mathrm{KCl}$ fertilizer, NPK-Phonska fertilizer, and herbicides only affect the income of shallot farming in Cirebon. The price of ZA fertilizer only affects the income of shallot farming in Brebes. The price of SP 36 fertilizer is only significant to the income in Nganjuk Regency. Based on these results, the government is expected to take part by providing subsidies for the procurement of shallot seeds, so that the income of shallot farmers will increase.

\section{ACKNOWLEDGMENT}

The authors thank Dr. Witono Adiyoga from BALITSA Lembang Bandung; Professor Siti Subandiyah and Professor Masyhuri from the Faculty of Agriculture, Universitas Gadjah Mada for giving us the opportunity to join ACIAR (Australian Centre for International Agriculture Research) project in 2013-2015. The authors also thank ACIAR for providing fund to conduct this research.

\section{REFERENCES}

[1] S. Markme and P. Nathewet. "Study of genetic diversity in shallot (Allium ascalonicum) of north Thailand using SSR markers," presented at the 54th Katsetsart University Annual Conference, Kasetsart University Thailand, 2016.

[2] A.F. Siregar and T. Supriana. "Factors that Influence the Interests of Farmer in Shallots Farming at Cinta Dame Village of Simanindo Sub District of Samosir district". IOP Conference Series : Earth and Environment Science, vol 122, 2015.

[3] A. Shimeles. "The Performance of True Seed Shallot Lines Under Different Environments of Ethiopia". Journal of Agricultural Sciences, vol 52, pp. 129-139, 2014.

[4] L. Rahmadona, A. Fariyanti and Burhanuddin. "Farming Income of Shallot Analysis in Majalengka Regency". AGRISE, vol 15, pp. 7284,2005

[5] T. Crowther, H.A. Collin, B. Smith, A. Tomsett, D. O'Connor and M.G. Jones. "Assessment of the flavour of fresh uncooked onions by taste-panels and analysis of flavor precursors, pyruvate and sugars". J Sci Food Agric, vol 85, pp. 112-120, 2005.

[6] Susanawati, Jamhari, Masyhuri, and H.D. Dwidjono. "Identifikasi Risiko Rantai Pasok Bawang Merah di Kabupaten Nganjuk”. Journal of Agribusiness and Rural Development Research, vol 3, pp. 15-22, 2017.

[7] B.O. Anyanwu. Agricultural Science For School and College. Onistha, Nigeria: Africa First Publisher, 2003.

[8] E. Rahayu and N. Berlian. The Shallot. Jakarta: Penebar Swadaya, 1998.

[9] R.A. Baloch. "Economic Analysis of Onion (Allium cepa L.) Production and Marketing in District Awaran, Balochistan". Journal of Economics and Sustainable Development, vol 5, pp. 1-15, 2014.

[10] Sujarwo, M.R. Reed and S.H. Saghaian. "Changing Technical, Allocative, and Economic Production Efficiency of Small-Scale Farmers in Indonesia: The Case Shallot Production". Journal of International Agricultural Trade and Development, vol 10, pp. 31$51,2014$.
[11] Directorate of Horticulture. "The Development of Commudity Production Holticulture Major Year 2011-2012." Internet: www.hortikultura.pertanian.go.id, Nov, 2015 [Sept. 2, 2018]

[12] Susanawati, Jamhari, Masyhuri and H.D. Dwijono. "Shallot Farming Performance in Java Indonesia". International Journal of Agricultural Sciences and Veterinary Medicine, vol 4, pp. 1-11, 2016.

[13] Mubyarto. Introduction Agricultural Economic. Jakarta: LP3ES, Indonesia, 1989.

[14] L. Wattimena. "Farming Income Analysis in Ambon City." Thesis. Magister Program, Gadjah Mada University, Yogyakarta, 2009.

[15] Soekartawi. Farming Analysis. Indonesia, Jakarta: PT Raja Grafindo Persada, 1994.

[16] V. Silvia, S. Muhammad, R. Masbar and M. Nasir. "Optimization of Smallholder Palm Oil in Nagan Raya and Aceh Tamiang Aceh Province”. International Journal of Contemporary Sciences, vol 3 , pp. 1-17, 2016.

[17] S.S. Takare, N.V. Shende and K.J. Shinde. "Mathematical Modeling for Demand and Supply Estimation for Cotton in Maharashtra". International Journal of Scientific Research Publication, vol 3, pp. 27-31, 2012.

[18] P.A. Yotopaulu, and J.B. Nugent. Economics of Development: Empirical Investigation. New York: Harper and Row Publisher, 1976.

[19] Rifiana, K. Wilda and Y. Ferianta. "Analysis of Profit Function and Returns to Scale of Rice Farming in Tidal and Fresh Water Swamplands in South Kalimantan". Tropical Wetland Journal, vol 3 , pp. 1-9, 2017.

[20] R.A. Novia. "Production Analysis, Income and Rice Farmer Household Food Sovereignty in Banyumas Regency." Thesis. Magister Program, Gadjah Mada University, Yogyakarta, 2012.

[21] A. Widarjono. "Econometrica, Theory and Application : For Economy and Business". Ekonisia. Faculty of Economy. Islamic University of Indonesia. Yogyakarta, 2007.

[22] M.M. Abd-el Rahman and M.T. Ebeaid. "Some Factors Affecting Artificial Curing of Onion Bulbs and Its Effects on Storability". Misr J. Agric. Eng, vol 26, pp. 905-921, 2009.

[23] T. Nurasa and V. "Darwis. Farming Analysis and Performance of Shallot Marketing Margin in Brebes Regency". Journal Akta Agrosia, vol 10, pp. 40-48, 2007.

[24] Triyono, I. Rosyadi and F. Ahyani. "Management Efficiency of Shallot Market”. Dinamika Sosial Ekonomi, vol 6, pp. 1-14, 2010.

[25] E.R. Palupi, F. Manik and M.R. Suhartanto, M.R. "Can We Produce True Seed of Shallot (TSS) from Small Size Shallot Sets?". Journal of Tropical Crop Science, vol 4, pp. 1-6, 2017.

[26] R. Purba. "Applications of NPK Phonska and KCl Fertilizer for the Growth and Yield of Shallots (Allium Ascalonicum) in Serang, Banten”. International Journal of Applied Science and Technology, vol 4, pp. 1-7, 2014 